\title{
ANTESEDEN DAN KONSEKUENSI AUDIT DELAY PADA PERUSAHAAN PERBANKAN PERIODA 2011-2014
}

\author{
Ronald Tehupuring \\ Mahasiswa Pascasarjana Universitas Gadjah Mada Yogyakarta \\ tehupuringronald@yahoo.co.id \\ Theresia Febiengry Sitanala \\ Fakultas Ekonomi, Universitas Pattimura Ambon \\ feisha_1011@yahoo.ca
}

\begin{abstract}
Timeliness in financial reporting can contribute to efficient performance for the stock market because it can reduce the asymmetry information, mitigate insider trading, and improve the usefulness decision of information to stakeholders. There were inconsistencies in prior research and the case of delay submission on issuer financial statements to the Financial Service Authority. There were 30 cases for each in 2013 and 2014. This study aimed to examine (1) the negative impact between the company size, profitability, leverage, and the auditor quality on audit delay; (2) the positive impact of audit delay on audit switching; and (3) the positive impact of audit delay and audit delay switching on audit quality in banking companies listed on the Stock Exchange 2011-2014 period. A purposive sampling method is used and as the sample, 30 companies are obtained in four years so the analyzed data was based on 120 observations. The data analysis technique used is multiple linear and logistic regression. Results showed that (1) the size of the company and leverage have no impact on audit delay, while the return on assets and the auditor quality have a negative impact and significantly related to audit delay; (2) audit delay has a positive impact and significantly related to audit switching; (3) audit delay has a positive impact and significantly related to audit quality, while audit switching has no impact on audit quality. This study has contributed in optimizing timeliness performance of financial information reporting, effectiveness and efficiency of audit time range so that general information increased, and The implication for audit quality of financial statements become more reliable.
\end{abstract}

Keywords: determinants of audit delay, audit switching, audit quality

\begin{abstract}
ABSTRAK
Ketepatwaktuan dalam pelaporan keuangan dapat memberikan kontribusi kinerja yang efisien bagi pasar modal karena dapat mengurangi asimetri informasi, memitigasi insider trading dan meningkatkan keputusan kegunaan informasi bagi stakeholders. Adanya ketidakonsistenan penelitian terdahulu serta fenomena kasus keterlambatan penyampaian laporan keuangan emiten ke Otoritas Jasa Keuangan tercatat sebanyak 30 kasus untuk masing-masing tahun 2013 dan 2014, sehingga penelitian ini bertujuan untuk menguji (1) pengaruh negatif antara ukuran perusahaan, profitabilitas, leverage
\end{abstract}


dan kualitas auditor terhadap audit delay; (2) pengaruh positif audit delay terhadap audit switching dan (3) pengaruh positif audit delay dan audit switching terhadap kualitas audit pada perusahaan perbankan yang terdaftar di BEI periode 2011-2014. Metoda pengambilan sampel menggunakan purposive sampling dan diperoleh sampel sebanyak 30 perusahaan selama empat tahun, sehingga data yang dianalisis sebanyak 120 amatan. Teknik analisis data yang digunakan adalah regresi linier berganda dan logistik. Hasil penelitian menunjukkan bahwa (1) ukuran perusahaan dan leverage tidak berpengaruh terhadap audit delay, sedangkan return on asset dan kualitas auditor memiliki pengaruh negatif dan signifikan terhadap audit delay; (2) audit delay memiliki pengaruh positif dan signifikan terhadap audit switching; (3) audit delay memiliki pengaruh positif dan signifikan terhadap kulitas audit, sedangkan audit switching tidak berpengaruh terhadap kualitas audit. Penelitian ini memiliki kontribusi dalam mengoptimalkan kinerja terkait ketepatwaktuan pelaporan informasi keuangan, efektivitas dan efisiensi rentang waktu audit sehingga nilai informasi secara umum mengalami peningkatan dan berimplikasi terhadap kualitas audit atas laporan keuangan menjadi lebih andal.

Kata kunci: determinan audit delay, audit switching, kualitas audit

\section{PENDAHULUAN}

Ketepatwaktuan dalam pelaporan keuangan merupakan salah satu karakteristik informasi akuntansi. Pelaporan keuangan yang tepat waktu dapat memberikan kontribusi kinerja yang efisien bagi pasar modal karena dapat mengurangi asimetri informasi dan meningkatkan keputusan kegunaan informasi bagi investor dan pengguna lainnya. Penundaan pelaporan keuangan akan mengakibatkan investor mencari alternatif sumber informasi dan akan memengaruhi basis investasi dalam perusahaan (Bamber et al., 1993).

Givoly dan Palmon (1982) menyatakan bahwa salah satu faktor penting dalam menentukan ketepatwaktuan pelaporan keuangan adalah lamanya waktu penyelesaian audit. Lamanya waktu penyelesaian audit akan memengaruhi reaksi pasar terhadap keterlambatan informasi keuangan, ketepatan waktu publikasi informasi keuangan yang telah diaudit, serta ketidakpastian keputusan yang didasarkan pada informasi yang telah dipublikasi. Sebagai tambahan, Owusu-Ansah (2000) menyatakan bahwa pelaporan keuangan yang tepat waktu penting untuk memitigasi insider trading dan rumor di pasar modal negara berkembang.

Di Indonesia khususnya, perusahaan yang telah terdaftar di pasar modal Indonesia harus menyerahkan laporan keuangan tahunan auditan kepada Bapepam-LK yang diatur dalam Undang-Undang No.8 tahun 1995 tentang kewajiban penyampaian publikasi laporan keuangan tahunan auditan. Penyerahan tersebut bersifat wajib selama batas waktu 120 hari dari akhir tahun fiskal sampai dengan diserahkannya laporan keuangan yang telah diaudit oleh Bapepam-LK. Peraturan tersebut kemudian diganti dengan peraturan baru dengan Nomor X.K2 tentang kewajiban penyampaian laporan keuangan berkala ke Bapepam-LK selambat-lambatnya akhir bulan ketiga (90 
hari) sejak tanggal 30 september 2003. Bapepam-LK sejak 12 Desember 2012 telah berganti namanya menjadi Otoritas Jasa Keuangan (OJK).

Fenomena terkait kasus pelanggaran ketentuan dan keterlambatan penyampaian laporan keuangan emiten ke Otoritas Jasa Keuangan masih saja terjadi di dua tahun terakhir yaitu tahun 2013 hingga 2014 yang dilakukan oleh beberapa perusahaan publik sejak tanggal 2 Januari 2013-13 Agustus 2013 dan tahun 2014 masing-masing tercatat 30 kasus yang menimpa emiten. Kasus ini disebabkan oleh berbagai macam faktor seperti tingkat profitabilitas perusahaan, tingkat leverage, ukuran perusahaan maupun kualitas auditor.

Untuk meningkatkan keandalan atas laporan keuangan maka dibutuhkan auditor yang independen dan objektif untuk mengaudit laporan keuangan perusahaan. Freeman (1994) memperkenalkan teori stakeholder, yang menyatakan bahwa perusahaan adalah organisasi yang berhubungan dengan pihak lain yang berkepentingan yaitu pihak internal dan pihak eksternal perusahaan, sehingga sebagai bentuk pertanggungjawaban perusahaan kepada pemangku kepentingan, maka perusahaan perlu melaporkan informasi keuangan yang memerlukan pihak ketiga berupa auditor yang independen dan objektif agar terjamin akuntabilitas, transaparansi, dan kualitas informasi laporan keuangan. Adanya hubungan kerjasama yang lama antara auditor dan klien dapat memengaruhi independensi auditor. Jensen dan Meckling (1976) menyatakan bahwa masalah keagenan timbul karena adanya konflik kepentingan dan asimetri informasi antara agen dan prinsipal, sehingga memicu adanya biaya keagenan. Dalam kaitannya dengan teori agensi, auditor independen berperan sebagai mediator antara agen dan prinsipal yang memiliki perbedaan kepentingan. Selain itu juga auditor independen berfungsi untuk mengurangi biaya agensi yang timbul atas konflik kepentingan yang terjadi, sehingga untuk mencegah hilangnya independensi auditor maka pemerintah mengatur kewajiban rotasi bagi auditor. Keharusan untuk melakukan rotasi auditor di Indonesia diatur dalam Peraturan Menteri Keuangan Republik Indonesia Nomor 17/PMK.01/2008 Pasal 3 yang sudah diberlakukan sejak tanggal 5 Februari 2008.

Audit switching pada kenyataannya dilakukan perusahaan karena beberapa faktor. Siegel et al. (2008) menjelaskan bahwa pemberhentian auditor dapat terjadi karena hubungan yang tidak baik antara auditor dan klien, perputaran staf audit yang tinggi dan ketidaksepakatan dalam akuntansi. Chadegani et al. (2011) menemukan bahwa perusahaan-perusahaan melakukan audit switching karena adanya pergantian manajemen, kondisi financial distress, audit fee dan upaya untuk meningkatkan kualitas audit.

Kecurigaan dari para pemakai laporan keuangan dan pihak eksternal lainnya timbul apabila terjadi audit switching yang dilakukan diluar prosedur yang berlaku, maka faktor penyebab dilakukannya audit switching perlu untuk diketahui. Menurut Nasser et al. (2006), pergantian KAP cenderung mengakibatkan peningkatan fee audit 
sehingga audit switching dapat menimbulkan dampak negatif. Selain itu, penugasan pertama terbukti memiliki kemungkinan kekeliruan yang tinggi. Dari beberapa sisi negatif di atas dengan demikian perusahaan seharusnya melakukan pertimbangan dan perencanaan sebelum melakukan audit switching.

Penelitian-penelitian sebelumnya menunjukkan hasil yang tidak konsisten mengenai determinan audit delay, pengaruh audit delay terhadap audit switching serta pengaruh audit delay dan audit switching terhadap kualitas audit. Prabowo dan Marsono (2013) menunjukkan bahwa ukuran perusahaan yang diukur dengan total aset berpengaruh positif terhadap audit delay. Sementara hasil penelitian yang dilakukan oleh Kartika (2011) menunjukkan bahwa ukuran perusahaan berpengaruh negatif terhadap audit delay. Hasil penelitian tersebut berbeda dengan hasil penelitian yang dilakukan oleh Ahmad dan Kamarudin (2003), Givoly dan Palmon (1982), serta Vuko dan Cular (2014) yang menemukan bahwa ukuran perusahaan tidak berpengaruh terhadap audit delay. Almosa dan Alabbas (2007) menemukan bahwa profitabilitas berhubungan positif dengan audit delay. Vuko dan Cular (2014) menemukan bahwa profitabilitas yang diproksi dengan return on asset berpengaruh negatif terhadap audit delay. Sementara Aryati (2005) menunjukkan bahwa tingkat profitabilitas tidak berpengaruh terhadap audit delay. Hasil penelitian yang dilakukan oleh Carslaw dan Kaplan (1991) serta Wirakusuma (2004) menemukan bahwa leverage yang diproksi dengan gearing ratio tidak berpengaruh terhadap audit delay. Sedangkan Vuko dan Cular (2014) menunjukkan bahwa terdapat pengaruh positif antara leverage dan audit delay; Aljabr (2007) menemukan bahwa leverage memiliki hubungan negatif dengan audit delay.

Faktor kualitas auditor menurut hasil penelitian DeAngelo (1981) dan Giling (1977) menunjukkan bahwa kualitas auditor berhubungan positif dengan audit delay. Sementara hasil penelitian yang dilakukan oleh Ashton et al. (1989); Schwartz dan Soo (1996); Ahmad dan Kamarudin (2003); Al-Ghanem dan Hegazy (2011) menemukan bahwa kualitas auditor berhubungan negatif dengan audit delay. Hasil penelitian Carslaw dan Kaplan (1991), Hossain dan Taylor (1998) menemukan bahwa kualitas auditor tidak berhubungan dengan audit delay.

Enofe et al. (2013) menemukan bahwa audit delay berpengaruh positif terhadap kualitas audit, sementara penelitian yang dilakukan oleh DeAngelo (1981) menunjukkan bahwa KAP yang lebih besar menghasilkan kualitas audit yang lebih tinggi untuk melindungi reputasinya sebagai akuntan publik yang independen. Cameran et al. (2016) menemukan bahwa tidak ada perbedaan yang signifikan dari kualitas audit sebelum dan setelah audit switching dilakukan. Sementara Mgbame et al. (2012) mengungkapkan bahwa audit tenure berhubungan negatif dengan kualitas audit, sehingga dengan adanya audit switching akan dapat meningkatkan kualitas audit. Dopuch et al. (2001) menemukan bahwa audit switching berpengaruh positif terhadap kualitas audit. 
Konflik kepentingan antara prinsipal dan agen disebabkan karena adanya asimetri informasi. Oleh karena itu, dibutuhkan auditor sebagai mediator untuk memitigasi asimetri informasi tersebut, sehingga tidak terjadi kecurangan atau penyampaian informasi yang tidak sesuai yang dapat menimbulkan lamanya waktu penyelesaian audit yang berkepanjangan yang berimplikasi pada kualitas audit. Penelitian ini dilakukan dengan tujuan untuk menguji kembali ketidakonsistenan penelitian terdahulu serta fenomena terkait keterlambatan penyampaian informasi pelaporan keuangan yang akan berdampak pada kualitas audit seperti yang telah dijelaskan sebelumnya.

Pertanyaan penelitian ini adalah: (1) apakah ukuran perusahaan, return on asset, leverage dan kualitas auditor berpengaruh negatif terhadap audit delay?; (2) apakah audit delay berpengaruh positif terhadap audit switching?; dan (3) apakah audit delay dan audit switching berpengaruh positif terhadap kualitas audit? Penelitian ini memberikan manfaat (1) bagi perkembangan literatur akuntansi khususnya yang berkaitan dengan tenggang waktu audit report, audit switching dan kualitas audit, (2) sebagai rujukan bagi perusahaan dalam menyusun laporan keuangan yang lebih berkualitas serta perusahaan selektif dalam menggunakan jasa KAP untuk mengurangi audit delay dan meningkatkan kualitas audit, selain itu juga (3) sebagai masukan bagi auditor dalam meningkatkan kualitas kinerja audit.

\section{KAJIAN PUSTAKA DAN PERUMUSAN HIPOTESIS}

\section{Ukuran Perusahaan dan Audit Delay}

Ukuran perusahaan sebagai bagian dari karakteristik perusahaan menunjukkan besar kecilnya suatu perusahaan atau badan usaha. Keterlambatan penyampaian informasi keuangan sering dihubungkan dengan ukuran perusahaan karena manajemen perusahaan yang berskala besar lebih mungkin untuk mengurangi audit delay dibandingkan dengan perusahaan berskala kecil. Penelitian-penelitian sebelumnya telah menggunakan total aset sebagai ukuran perusahaan yang dihubungkan dengan audit delay di antaranya penelitian Courtis (1976); Giling (1977); Davies dan Whittred (1980); Garsombke (1981); Ashton et al. (1989); Newton dan Ashton (1989); Carslaw dan Kaplan (1991); Ng dan Tai (1994); Abdulla (1996); Hossain dan Taylor (1998); Jaggi dan Tsui (1999); Owusu-Ansah (2000); Ahmad dan Kamarudin (2003); Ahmed (2003); Leventis et al. (2005); Al-Ajmi (2008); Ibadin et al. (2012); Modugu et al. (2012); serta Ayemere dan Elijah (2015).

Sebagian besar dari hasil penelitian terdahulu menemukan adanya hubungan negatif antara ukuran perusahaan dan audit delay. Carslaw dan Kaplan (1991) menyatakan bahwa perusahaan besar kemungkinan memiliki pengendalian internal yang kuat sehingga mengurangi kecenderungan kesalahan laporan keuangan dan memungkinkan auditor untuk mengandalkan kontrol yang lebih luas dalam menyelesaikan pekerjaan mereka. Selain itu juga, perusahaan besar mungkin 
memberikan tekanan kepada auditor untuk menyelesaikan audit dengan tepat waktu. Lebih lanjut, Owusu-Ansah (2000) menyatakan bahwa perusahaan besar memiliki lebih banyak sumber daya untuk membayar biaya audit yang relatif lebih tinggi dan mampu menyelesaikan biaya segera setelah akhir tahun perusahaan, memiliki sistem informasi akuntansi yang canggih yang menghasilkan laporan tahunan yang lebih tepat waktu. Akhirnya, perusahaan besar lebih tepat waktu dalam menginformasikan laporan keuangannya dibandingkan perusahaan kecil karena mereka dipantau lebih ketat oleh para pemangku kepentingan Dyer dan McHugh (1975). Berdasarkan argumentasi dan hasil riset terdahulu, maka hipotesis pertama yang diajukan adalah sebagai berikut.

H1: Ukuran perusahaan memiliki pengaruh negatif terhadap audit delay.

\section{Profitabilitas dan Audit Delay}

Profitabilitas menunjukkan penggunaan sumber daya yang dimiliki oleh perusahaan secara efisiensi untuk mengoptimalkan laba. Perolehan laba biasanya dijadikan tolok ukur kinerja perusahaan karena memberikan good news kepada pemangku kepentingan mengenai kondisi perusahaan. Perusahaan yang mengumumkan laba cenderung memiliki audit delay yang pendek karena informasi terkait kondisi perusahaan ingin segera diberitahukan kepada pemangku kepentingan.

Banyak penelitian-penelitian terdahulu yang membahas mengenai hubungan profitabilitas dan audit delay Dyer dan McHugh (1975); Carslaw dan Kaplan (1991); Bamber et al. (1993); Almosa dan Alabbas (2007); Abdulla (1996). Berdasarkan hasil penelitian terdahulu diatas, ditemukannya adanya hubungan negatif antara profitabilitas dan audit delay. Ashton et al. (1989) menyatakan bahwa profitabilitas dianggap sebagai indikasi good news atau bad news yang dihasilkan dari operasi tahun ini. Lebih lanjut, Hossain dan Taylor (1998) menjelaskan bahwa perusahaan yang mengalami bad news dapat meminta auditor mulai menjadwalkan audit kemudian dari biasanya, sementara perusahaan yang mengalami good news diharapkan meminta auditor untuk memulai perikatan audit awal untuk merilis laporan keuangan yang diaudit agar lebih cepat sehingga perusahaan yang melaporkan laba untuk periode tersebut diharapkan untuk meminimalkan audit delay. Argumentasi dan riset terdahulu menjadi dasar penyusunan hipotesis sebagai berikut.

H2: Profitabilitas dengan proksi return on asset memiliki pengaruh negatif terhadap audit delay.

\section{Leverage dan Audit Delay}

Leverage digunakan sebagai pengukur kemampuan perusahaan dalam memenuhi kewajiban keuangan baik itu kewajiban jangka pendek maupun kewajiban jangka panjang. Debt to equity ratio sebagai proksi dari leverage menggambarkan perbandingan hutang dengan ekuitas untuk melihat kemampuan perusahaan dalam 
memenuhi semua hutang dari ekuitas yang dimiliki perusahaan, sehingga rasio ini mengindikasikan tingkat kesehatan perusahaan. Apabila tingkat rasio ini meningkat (tinggi) maka akan meningkatkan kegagalan perusahaan dalam memenuhi kewajibannya sehingga kinerja perusahaan kurang baik.

Carslaw dan Kaplan (1991) menyatakan bahwa rasio utang yang tinggi akan meningkatkan kemungkinan gagalnya perusahaan dan dapat memungkinkan terjadinya kekhawatiran auditor bahwa laporan keuangan perusahaan mungkin kurang handal dari biasanya. Namun penelitian lain menunjukkan bahwa rasio utang perusahaan yang negatif berhubungan dengan waktu rilisnya informasi perusahaan (Aljabr 2007; Deloof dan Weet (2003). Berdasarkan uraian tersebut, maka hipotesis yang diajukan sebagai berikut.

H3: Leverage dengan proksi debt to equity ratio memiliki pengaruh negatif terhadap audit delay.

\section{Kualitas Auditor dan Audit Delay}

Jenis KAP sebagai bagian dari kualitas auditor sering digunakan untuk menjelaskan keterkaitannya dengan audit delay sebagai variabel penjelas. KAP diklasifikasikan menjadi dua kelompok, yaitu KAP yang berafiliasi dengan big four dan non-big four Ahmad dan Kamarudin (2003). Bebarapa peneliti berkeyakinan bahwa KAP yang berafiliasi dengan the big four memiliki akses lebih dalam hal kecanggihan teknologi sehingga dapat mengurangi audit delay dibandingkan KAP non big four.

Perusahaan yang diaudit oleh KAP yang berafiliasi dengan big four diharapkan akan berkurang audit delay dibandingkan perusahaan yang diaudit oleh KAP yang berafiliasi dengan non-big four Carslaw dan Kaplan (1991); Leventis et al. (2005). Ashton et al. (1989) menyatakan bahwa KAP big four cenderung menyelesaikan audit tepat waktu sehingga lebih efisien dan efektif dibandingkan KAP non-big four karena umumnya KAP big four memiliki sumber daya yang lebih besar, baik itu dari segi kompetensi, keahlian dan kemampuan auditor sehingga perusahaan yang diaudit oleh KAP big four memiliki waktu audit delay lebih singkat dibandingkan KAP non-big four. Berdasarkan uraian tersebut, maka hipotesis yang diajukan adalah sebagai berikut.

H4: Kualitas auditor memiliki pengaruh negatif terhadap audit delay.

\section{Audit Delay dan Audit Switching}

Stocken (2000) menyatakan bahwa suatu penyelesaian tugas audit yang memiliki rentang waktu yang terlalu lama akan mengakibatkan keterlambatan dalam mempublikasikan laporan keuangan ke pasar modal sehingga berpengaruh pada audit 
switching. Tingkat kerumitan yang tinggi mengakibatkan auditor memerlukan jumlah hari yang lebih banyak untuk mengaudit perusahaan induk beserta anak perusahaannya (Che-Ahmad \& Abidin 2008). Beberapa penelitian sebelumnya menyarankan untuk menguji secara empiris pengaruh dari audit delay karena belum banyak dilakukan pengujian terhadap variabel ini. Berdasarkan uraian tersebut, maka hipotesis yang diajukan adalah sebagai berikut.

H5: Audit delay memiliki pengaruh positif terhadap audit switching.

\section{Audit Delay dan Kualitas Audit}

Fagbemi dan Uadiale (2011) berpendapat bahwa informasi akuntansi yang baik biasanya ditandai dengan faktor-faktor seperti relevansi, kecukupan, komparabilitas dan keandalan agar informasi yang diberikan dapat bermanfaat untuk pengambilan keputusan oleh berbagai pemangku kepentingan. Menurut Fairchild (2007), kualitas audit adalah bahan dasar dalam meningkatkan kredibilitas laporan keuangan bagi pengguna informasi laporan keuangan. Keterlambatan atas hasil laporan keuangan menyebabkan terjadinya inefisiensi pasar yang lebih besar Ismail dan Chandler (2004) dan mengurangi relevansi dari isi informasi (Ahmad \& Kamarudin 2003). Dengan demikan, lamanya waktu penyelesaian audit dapat memengaruhi rentang waktu informasi yang dipublikasikan sehingga berdampak pada kualitas audit yang dihasilkan. Berdasarkan uraian tersebut, maka hipotesis yang diajukan sebagai berikut.

H6: Audit delay memiliki pengaruh positif terhadap kualitas audit.

\section{Audit Switching dan Kualitas Audit}

Beberapa penelitian yang mendukung regulasi pergantian audit seperti yang dilakukan oleh Hamilton et al. (2005), Chung (2004), Healey dan Kim (2003), AICPA (1992) menyatakan bahwa rotasi audit perusahaan adalah cara untuk meningkatkan kualitas audit. Lebih lanjut Mohmed (2010) mengakui bahwa rotasi audit dianggap sangat informatif untuk orang luar karena auditor pengganti mendapat informasi dari pendahulunya yang membantu dia dalam menilai kondisi keuangan perusahaan. Hasil penelitian yang dilakukan oleh Yazawa (2014) yang menyimpulkan bahwa regulasi pergantian audit berpengaruh signifikan dengan menurunnya kualitas laporan keuangan. Berdasarkan uraian tersebut, maka hipotesis yang diajukan sebagai berikut.

H7: Audit switching memiliki pengaruh positif terhadap kualitas audit.

\section{METODA PENELITIAN}

\section{Sampel dan Data Penelitian}

Jenis data dalam penelitian ini adalah data sekunder berupa laporan keuangan perusahaan perbankan periode 2011-2014. Metoda observasi non partisipan digunakan untuk mencatat data yang diakses melalui situs BEI dan website setiap perusahaan. Dengan menggunakan metoda purposive sampling (Lampiran Tabel 1) maka diperolah 
30 perusahaan dengan periode pengamatan 4 tahun, sehingga total sampel yang digunakan sebanyak 120 sampel.

Alasan dipilihnya sektor perbankan sebagai sampel adalah karena bank memiliki risiko usaha tinggi karena dengan gagalnya perusahaan perbankan maka dapat menjatuhkan perekonomian negara tersebut, selain itu juga perusahaan perbankan merupakan industri keuangan yang bersifat capital intensive.

\section{Definisi Operasional dan Pengukuran Variabel}

Ukuran perusahaan merupakan salah satu tolok ukur yang menunjukkan besar kecilnya perusahaan yang diukur dengan total aset yang dimiliki perusahaan dengan menggunakan logaritma natural. Profitabilitas adalah kemampuan perusahaan dalam menghasilkan laba. Profitabilitas dalam penelitian ini diproksi dengan return on asset yang merupakan analisis kemampulabaan yang memperlihatkan sejauhmana perusahaan mengelola modal sendiri secara efektif dan mengukur tingkat keuntungan dan investasi yang telah dilakukan oleh pemegang saham.

Dalam penelitian ini return on asset dapat dirumuskan sebagai berikut: $R O A=$ (Laba bersih/Total Aset) X 100\%. Leverage merupakan kebijakan perusahaan yang dilakukan untuk memperoleh sumber dana. Leverage diproksi dengan debt to equity ratio yang dirumuskan sebagai berikut: $D E R=$ (Total Utang/Ekuitas Pemegang saham) X 100\%. Kualitas auditor dalam penelitian ini merupakan besar kecilnya KAP yang dibedakan dalam dua kelompok, yaitu KAP besar (KAP yang berafiliasi dengan Big Four) dan KAP kecil (KAP yang tidak berafiliasi dengan Big Four). Jika perusahaan diaudit oleh KAP Big Four maka diberi nilai 1. Sedangkan jika perusahaan diaudit oleh KAP non Big Four maka diberi nilai 0.

KAP Big Four adalah Pricewaterhouse Coopers yang berafiliasi dengan Haryanto Sahari dan Rekan, Ernst and Young yang berafiliasi dengan Purwanto, Sarwoko \& Sandjaja, Deloitte yang berafiliasi dengan Osman Ramli Satrio dan Rekan, KPMG yang berafiliasi dengan Siddharta dan Widjaya. Ashton et al. (1989) menjelaskan bahwa audit delay merupakan lamanya waktu penyelesaian audit dimulai dari akhir tahun fiskal perusahaan sampai tanggal laporan audit dikeluarkan.

Audit delay dalam penelitian ini diukur dengan tanggal laporan auditor independen dikurangi tanggal tahun buku perusahaan yang berakhir dalam jumlah hari. Audit switching merupakan perpindahan auditor yang dilakukan oleh perusahaan klien. Dalam penelitian ini, audit switching diukur dengan variabel dummy dengan ketentuan berikut: jika perusahaan mengganti auditor (KAP) dengan auditor (KAP) tahun sebelumnya diberi angka 1 dan jika tidak pernah mengganti diberi angka 0 .

Kualitas audit adalah kesesuaian audit yang dilakukan oleh auditor dengan standar pengauditan Watkins et al. (2004). Kualitas audit dalam penelitian ini menggunakan model earnings surprise benchmark (Carey dan Simnett 2006). Kualitas audit ini digunakan untuk mengetahui manajemen laba yang dilakukan oleh suatu 
perusahaan dan kemampuan auditor dalam mengungkapkan adanya manajemen laba (manajemen menghindari pelaporan kerugian perusahaan). Rumus yang digunakan untuk menghindari pelaporan kerugian adalah earnings/total assets. Oleh karena itu, earnings/total asset atau ROA dipilih menjadi tolok ukur penentu kualitas audit. Kualitas audit dinyatakan dengan variabel dummy 1 untuk kualitas audit baik dan 0 untuk kualitas audit tidak baik. Penentunya adalah ROA atau earnings/total assets masing- masing perusahaan, apakah terdapat dalam benchmark ataukah tidak. Benchmark-nya adalah $\mu-\sigma<R O A<\mu+\sigma, \mu$ adalah rata-rata $R O A$ seluruh perusahaan sampel dan $\sigma$ adalah deviasinya. ROA yang masuk dalam benchmark menandakan kualitas audit yang baik (1). Sedangkan kualitas audit diasumsikan buruk atau tidak baik (0) apabila: (1) laba melebihi earnings benchmark yaitu ketika nilai $R O A>\mu+\sigma$, yang diartikan bahwa auditor memberi kesempatan kepada perusahaan untuk melakukan praktik "windows dressing" (adalah usaha manajemen untuk membuat laporan keuangan menjadi "bagus" dengan meningkatkan laba sehingga manajemen dapat menikmati bonus dimasa kini). (2) Rugi melebihi earnings benchmark yaitu ketika nilai $R O A<\mu-\sigma$, yang diartikan bahwa auditor memberi kesempatan perusahaan untuk melakukan praktik "taking a bath" (adalah usaha manajemen untuk membuat laporan keuangan menjadi "jelek" dengan meningkatkan rugi dengan harapan manajemen akan mendapat bonus di masa depan karena laba yang meningkat). Dengan demikian dapat dirumuskan variabel dependen kualitas audit (MEET_BE) adalah sebagai berikut:

a. MEET_BE $=1$ ketika memenuhi kriteria $\mu \sigma<R O A<\mu+\sigma$, menunjukkan kualitas audit yang tinggi.

b. MEET_BE $=0$ untuk $R O A>\mu+\sigma$ dimana manajemen melakukan praktik "windows dressing" atau ROA $<\mu-\sigma$ dimana manajemen melakukan praktik "taking a bath", yang menunjukkan kualitas audit yang rendah.

Agar model regresi tidak bias (BLUE), maka diperlukan uji asumsi klasik terlebih dahulu sebelum uji regresi yang terdiri atas uji normalitas, uji multikolinearitas, uji heteroskedastisitas dan uji autokorelasi (Gujarati 2003). Uji normalitas digunakan untuk mengetahui apakah residual memiliki distribusi normal. Model regresi yang baik adalah yang mempunyai data berdistribusi normal atau mendekati normal. Dalam pengujian ini digunakan one sample Kolmogorov-smirnov. Data dikatakan berdistribusi normal jika signifikansi berada di atas 5 persen (Gujarati 2003).

Uji multikolinearitas bertujuan untuk menguji apakah dalam model regresi ditemukan adanya korelasi antar variabel independen. Model regresi yang baik adalah model yang tidak terjadi korelasi antara variabel independen. Pengambilan keputusan mengenai ada tidaknya korelasi antar variabel independen yaitu dengan melihat nilai tolerance dan nilai variance inflation factor. Gujarati (2003) mengatakan bahwa jika nilai tolerance lebih dari 0,1 dan nilai VIF yang tidak lebih dari 10 maka hubungan 
linier di antara variabel bebas dalam model regresi tidak mengandung multikolinearitas.

Uji heteroskedastisitas bertujuan untuk mengetahui apakah model regresi terjadi ketidaksamaan variance residual dari suatu pengamatan ke pengamatan yang lain. Jika variance residual dari suatu pengamatan ke pengamatan yang lain tetap maka disebut homokedastisitas dan jika berbeda disebut heteroskedastisitas. Model regresi yang baik adalah model regresi yang memenuhi asumsi homokedastisitas. Uji heteroskedastisitas dilakukan dengan uji glejser. Uji glejser dilakukan dengan mengabsolutkan nilai residual regresi dan menggunakan absolut tersebut sebagai variabel dependen. Pengujiannya dengan melihat signifikansi hasil dari regresi dengan absolut residual sebagai variabel dependen. Masalah heteroskedastisitas akan terjadi bila masing-masing variabel independen mempunyai nilai signifikansi lebih kecil dari alpha 0,05 (Gujarati 2003). Uji autokorelasi bertujuan untuk menguji apakah dalam model regresi linier ada korelasi antara kesalahan penganggu pada periode $t$ dengan kesalahan pengganggu pada periode t-1 (sebelumnya). Jika terjadi korelasi, maka ada masalah autokorelasi. Autokorelasi muncul karena observasi yang berurutan sepanjang waktu berkaitan satu sama lainnya. Masalah ini timbul karena residual (kesalahan pengganggu) tidak bebas dari satu observasi ke observasi lainnya. Pengambilan keputusan mengenai ada tidaknya autokorelasi adalah sebagai berikut: jika nilai Durbin-Watson diperoleh berada di antara -2 sampai dengan 2 maka diasumsikan tidak ada autokorelasi Santoso (2010).

Pengujian hipotesis menggunakan model regresi linier berganda dan logistik. Regresi linier berganda digunakan untuk menguji (1) pengaruh negatif ukuran perusahaan, profitabilitas, leverage dan kualitas auditor terhadap audit delay; sedangkan regresi logistik digunakan untuk menguji (1) pengaruh positif audit delay terhadap audit switching dan (2) pengaruh positif audit delay dan audit switching terhadap kualitas audit. Adapun persamaan matematis untuk pengujian hipotesis dalam penelitian adalah sebagai berikut

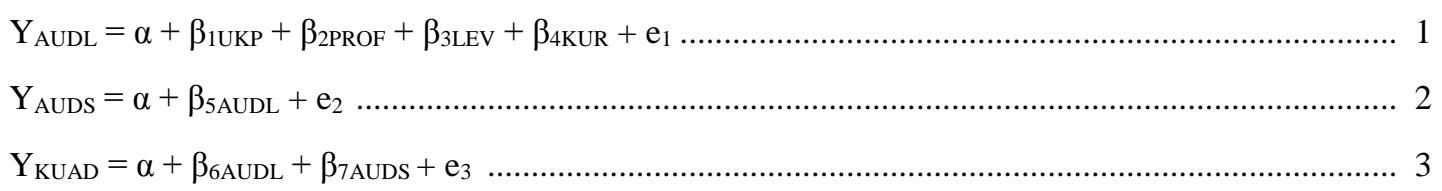

\section{ANALISIS DAN PEMBAHASAN}

\section{Analisis Statistik Deskriptif}

Perusahaan perbankan yang dijadikan sampel akan dianalisis menjadi dua kategori kelompok, yaitu kategori perusahaan dengan audit delay di bawah 90 hari dan perusahaan dengan audit delay diatas 90 hari dalam menyampaikan laporan keuangannya ke Otoritas Jasa Keuangan. Pengelompokan pada Tabel 2 (Lampiran) menunjukkan bahwa dari 30 perusahaan yang dapat dianalisis untuk tahun 2011 
terdapat 1 perusahaan atau sebesar 3,33 persen dengan audit delay di atas 90 hari dan 29 perusahaan atau sebesar 96,67 persen dengan audit delay dibawah 90 hari. Untuk tahun 2012 terdapat 2 perusahaan atau sebesar 6,67 persen dengan audit delay di atas 90 hari dan 28 perusahaan atau sebesar 93,33 persen dengan audit delay di bawah 90 hari. Untuk tahun 2013 terdapat 1 perusahaan atau sebesar 3,33 persen dengan audit delay di atas 90 hari dan 29 perusahaan atau sebesar 96,67 persen dengan audit delay di bawah 90 hari. Sedangkan untuk tahun 2014 tidak terdapat perusahaan dengan audit delay di atas 90 hari.

Berdasarkan Tabel 3 statistik deskriptif (Lampiran 1), rata-rata audit delay untuk perusahaan perbankan yang terdaftar di Bursa Efek Indonesia periode 20112014 adalah sebesar 64,5750 dengan nilai minimum audit delay adalah 16 hari dan maksimum adalah 136 hari, variabel ukuran perusahaan yang diproksi dengan jumlah aset perusahaan (UKP) memiliki mean sebesar 2,4702E, minimum sebesar 1217521,00, maksimum sebesar 9,50184E11 dan standar deviasi sebesar 9,50184E11; untuk variabel ukuran perusahaan yang di logaritma natural terlihat bahwa mean sebesar 19,4033, minimum sebesar 14,01, maksimum sebesar 29,28 dan standar deviasi sebesar 3,53900; profitabilitas yang diproksi dengan return on asset (ROA) memiliki mean sebesar 1,1792 dan standar deviasi sebesar 1,43101, minimum sebesar -7,79, maksimum sebesar 1562,03; leverage yang diproksi dengan Debt to Equity Ratio (DER) memiliki mean sebesar 763,2227 dan standar deviasi sebesar 309,17839, minimum sebesar -743,92, maksimum sebesar 1562,03.

Variabel kualitas auditor, audit switching dan kualitas audit tidak dimasukkan dalam perhitungan statistik deskriptif karena variabel tersebut memiliki skala nominal/kategorikal yang bernilai 1 dan 0 . Angka ini hanya berfungsi sebagai label kategori semata tanpa nilai intrinsik dan tidak memiliki arti apa-apa. Oleh sebab itu tidaklah tepat menghitung nilai rata- rata dan standar deviasi.

Berdasarkan Tabel 4 (Lampiran 1), hasil pengujian normalitas data dengan One Sample Kolmogorov-Smirnov Test, menunjukkan hasil yang tidak signifikan, yaitu lebih besar dari 0,05 (5 persen), sehingga pada masing-masing variabel yang digunakan dalam penelitian ini, memiliki pola distribusi data yang normal. Hasil pengujian menunjukkan bahwa model yang dipergunakan dalam penelitian ini tidak terdapat masalah multikolinearitas. Hal tersebut ditunjukkan dengan adanya nilai tolerance di antara dua variabel independen yang lebih besar dari 0,01 dan nilai VIF yang lebih kecil dari 10. Hasil pengujian heteroskedastisitas dengan uji one glejser, menunjukkan hasil yang tidak signifikan, yaitu lebih besar dari 0,05 (5 persen), sehingga pada masing-masing variabel yang digunakan dalam penelitian ini memiliki data yang homokedastisitas. Selanjutnya hasil pengujian autokorelasi dengan uji Durbin-Watson $(D W)$ menunjukkan bahwa nilai $D W$ statistik masih dalam batas toleransi seperti terlihat yaitu sebesar 1,283. 


\section{Hasil}

Pengujian hipotesis untuk model persamaan 1 menggunakan model regresi linier berganda yang digunakan untuk menguji pengaruh ukuran perusahaan, ROA, leverage dan kualitas auditor terhadap audit delay pelaporan keuangan perusahaan. Uji ANOVA pada Tabel 5 (Lampiran 2), menghasilkan nilai $F$ hitung sebesar 12,710 dengan probabilitas signifikansi sebesar 0,000 $(p<0,05)$. Hal ini menunjukkan bahwa pengaruh yang signifikan ukuran perusahaan, return on asset, leverage dan kualitas audit terhadap audit delay. Hasil ini juga menunjukkan bahwa model regresi dalam penelitian ini memenuhi kriteria goodness of fit.

Hasil analisis persamaan 1 diperoleh nilai $R$ square sebesar 0,307 hal ini berarti 30,7 persen variasi audit delay dapat dijelaskan oleh variasi ukuran perusahaan, return on asset, leverage dan kualitas auditor dan sisanya sebesar 69,3 persen dijelaskan oleh faktor- faktor lain di luar model. Selanjutnya, hasil pengujian hipotesis 1 menunjukkan bahwa ukuran perusahaan tidak berpengaruh negatif terhadap audit delay. Hasil regresi tersebut memiliki nilai t-test sebesar 0,925 dengan tingkat signifikansi hasil pengujian sebesar 0,357 lebih besar dibandingkan dengan tingkat signifikansi yang digunakan dalam penelitian ini, yaitu sebesar 0,05 (5 persen).

Hasil pengujian hipotesis 2 menunjukkan bahwa return on asset berpengaruh negatif dan signifikan terhadap audit delay. Hasil regresi tersebut memiliki nilai $t$-test sebesar -2,949 dengan tingkat signifikansi hasil pengujian sebesar 0,004 lebih kecil dibandingkan dengan tingkat signifikansi yang digunakan dalam penelitian ini, yaitu sebesar 0,05 (5 persen). Hasil pengujian hipotesis 3 menunjukkan bahwa leverage tidak berpengaruh negatif terhadap audit delay. Hasil regresi tersebut memiliki nilai $t$ test sebesar 0,274 dengan tingkat signifikansi hasil pengujian sebesar 0,785 lebih besar dibandingkan dengan tingkat signifikansi yang digunakan dalam penelitian ini, yaitu sebesar 0,05 (5 persen). Hasil pengujian hipotesis 4 menunjukkan bahwa kualitas auditor berpengaruh negatif dan signifikan terhadap audit delay. Hasil regresi tersebut memiliki nilai $t$-test sebesar -4,776 dengan tingkat signifikansi hasil pengujian sebesar 0,000 lebih kecil dibandingkan dengan tingkat signifikansi yang digunakan dalam penelitian ini, yaitu sebesar 0,05 (5 persen).

Pengujian hipotesis untuk model persamaan 2 dan persamaan 3 menggunakan model regresi logistik. Untuk pengujian hipotesis model persamaan 2 pada Tabel 5 (Lampiran), dapat dilihat bahwa nilai goodness of fit test yang diukur dengan nilai Chisquare pada bagian bawah uji Hosmer and Lemeshow. Angka probabilitas sebesar $0,136>0,05$. Hal ini berarti bahwa model regresi layak dipakai untuk analisis selanjutnya karena tidak terdapat perbedaan nyata antara klasifikasi yang diprediksi dengan klasifikasi yang diamati.

Langkah berikutnya adalah menilai keseluruhan model (overall model fit) dengan memperhatikan angka -2 log likelihood yaitu pada awal (block number $=0$ ) angka -2 LL adalah 112,442 sedangkan block number = 1, angka -2 LL turun menjadi 
107,714. Penurunan $L L$ menunjukkan model regresi yang lebih baik. Untuk nilai Negelkerke $R$ square sebesar 0,086 yang artinya bahwa variabel audit delay mampu menjelaskan audit switching sebesar 8,6 persen dan sisanya yaitu sebesar 91,4 persen dijelaskan oleh faktor lain di luar model. Hasil pengujian koefisien regresi hipotesis 5 menunjukkan bahwa nilai koefisien regresi sebesar 0,031 dengan tingkat signifikansi $0,017<0,05$. Dengan demikian terbukti bahwa audit delay berpengaruh positif dan signifikan terhadap audit switching. Untuk pengujian hipotesis model persamaan 3 pada Tabel 5 (dalam lampiran), dapat dilihat bahwa nilai goodness of fit test yang diukur dengan nilai Chi-square pada bagian bawah uji Hosmer and Lemeshow. Angka probabilitas sebesar 0,353>0,05. Hal ini berarti bahwa model regresi layak dipakai untuk analisis selanjutnya karena tidak terdapat perbedaan nyata antara klasifikasi yang diprediksi dengan klasifikasi yang diamati.

Langkah berikutnya adalah menilai keseluruhan model (overall model fit) dengan memperhatikan angka -2 log likelihood(LL) yaitu pada awal (block number = 0) angka -2 $L L$ adalah 86,232 sedangkan block number $=1$, angka $-2 L L$ turun menjadi 80,516. Penurunan $L L$ menunjukkan model regresi yang lebih baik. Untuk nilai Negelkerke $R$ square sebesar 0,173 yang artinya bahwa variabel audit delay dan audit switching mampu menjelaskan kualitas audit sebesar 17,3 persen dan sisanya yaitu sebesar 82,3 persen dijelaskan oleh faktor lain di luar model. Selanjutnya, hasil pengujian koefisien regresi hipotesis 6 menunjukkan bahwa nilai koefisien regresi sebesar 0,051 dengan tingkat signifikansi 0,002<0,05. Dengan demikian audit delay berpengaruh positif dan signifikan terhadap kualitas audit. Hasil pengujian koefisien regresi hipotesis 7 dapat menunjukkan bahwa nilai koefisien regresi sebesar -0,592 dengan tingkat signifikansi 0,505>0,05. Dengan demikian audit delay tidak berpengaruh positif dan signifikan terhadap kualitas audit.

Hipotesis 1 yang menyatakan bahwa ukuran perusahaan mempunyai pengaruh negatif terhadap audit delay secara empiris tidak terdukung. Hal ini dapat disebabkan karena perusahaan yang telah go public selalu dipantau dengan ketat oleh pemangku kepentingan sehingga baik itu perusahaan yang berskala kecil maupun berskala besar memiliki tekanan yang sama dalam menyampaikan laporan keuangan. Selain itu juga proksi ukuran perusahaan yaitu total aset kemungkinan belum tepat dalam menjelaskan pengaruh ukuran perusahaan terhadap audit delay bila dibandingkan penjualan. Hasil penelitian ini konsisten dengan hasil penelitian yang dilakukan oleh Givoly dan Palmon (1982), Ahmad dan Kamarudin (2003), Vuko dan Cular (2014) yang menemukan bahwa ukuran perusahaan tidak berpengaruh terhadap audit delay.

Hipotesis 2 yang menyatakan bahwa profitabilitas yang diproksi dengan return on asset mempunyai pengaruh negatif terhadap audit delay secara empiris terdukung. Hasil penelitian ini menunjukkan bahwa perusahaan dengan profitabilitas tinggi akan cenderung mengungkapkan informasi keuangan mereka dengan lebih cepat untuk menyampaikan informasi good news kepada pemangku kepentingan. Semakin tinggi ROA maka akan semakin pendek audit delay. Hasil penelitian ini konsisten dengan 
hasil penelitian yang dilakukan oleh Courtis (1976) yang menunjukkan bahwa variabel yang paling berpengaruh signifikan adalah tingkat profitabilitas yang diukur dengan ROA.

Hipotesis 3 yang menyatakan bahwa leverage yang di proksi dengan debt to equity ratio mempunyai pengaruh negatif terhadap audit delay secara empiris tidak terdukung. Hal ini mengindikasikan bahwa perusahaan yang memiliki debt to equtiy ratio (DER) yang tinggi cenderung mengalami audit delay yang lama dibandingkan perusahaan dengan $D E R$ yang rendah. Dengan tingginya $D E R$ perusahaan maka risiko keuangan pun semakin meningkat yang berarti bahwa perusahaan mengalami kesulitan keuangan akibat utang yang tinggi sehingga pihak manajemen perusahaan cenderung untuk menunda penyampaian laporan keuangan. Hasil penelitian ini konsisten dengan hasil penelitian yang dilakukan oleh (Carslaw \& Kaplan 1991).

Hipotesis 4 yang menyatakan bahwa kualitas auditor mempunyai pengaruh negatif terhadap audit delay secara empiris terdukung. Hal ini menunjukkan bahwa penggunaan Kantor Akuntan Publik (KAP) yang berafiliasi dengan big four akan mendorong perusahaan menyampaikan laporan keuangan dengan tepat waktu. Hasil penelitian ini konsisten dengan hasil penelitian yang dilakukan oleh Ashton et al. (1989); Schwartz dan Soo (1996); Ahmad dan Kamarudin (2003) serta Al-Ghanem dan Hegazy (2011) menemukan bahwa kualitas auditor berhubungan negatif dengan audit delay.

Hipotesis 5 yang menyatakan bahwa audit delay mempunyai pengaruh positif terhadap audit switching secara empiris terdukung. Hasil pengujian menunjukkan bahwa audit delay berpengaruh signifikan pada voluntary audit switching. Sesuai dengan Stocken (2000) yang menyatakan bahwa suatu penyelesaian tugas audit yang memiliki rentang waktu yang terlalu lama akan mengakibatkan keterlambatan dalam mempublikasikan laporan keuangan ke pasar modal sehingga berpengaruh pada audit switching. Apabila publikasi laporan keuangan mengalami keterlambatan maka pihak pasar modal akan curiga dan menilai negatif bahwa perusahaan sedang mengalami masalah.

Hipotesis 6 yang menyatakan bahwa audit delay mempunyai pengaruh positif terhadap kualitas audit secara empiris tidak terdukung. Hal ini berarti bahwa jika terdapat penundaan yang tidak semestinya dalam pelaporan maka informasi yang dihasilkan akan kehilangan relevansinya sehingga manajemen mungkin perlu menyeimbangkan manfaat antara pelaporan yang tepat waktu dengan kekuatan informasi yang andal. Hasil penelitian ini konsisten dengan hasil penelitian yang dilakukan oleh Enofe et al. (2013) yang menyatakan bahwa audit delay berpengaruh positif terhadap kualitas audit.

Hipotesis 7 yang menyatakan bahwa audit switching mempunyai pengaruh positif terhadap kualitas audit secara empiris tidak terdukung. Hal ini disebabkan oleh independensi auditor, biaya yang cukup besar, waktu yang cukup lama bagi KAP baru 
untuk mempelajari alur bisnis perusahaan, ataupun terdapat kemungkinan bahwa perusahaan takut akan terungkapnya semua kecurangan yang ada. Hasil penelitian ini konsisten dengan hasil penelitian yang dilakukan oleh Cameran et al. (2016) menemukan bahwa tidak ada perbedaan yang signifikan dari kualitas audit setelah dan sebelum audit switching dilakukan.

\section{SIMPULAN, KETERBATASAN DAN SARAN}

\section{Simpulan}

Penelitian ini menguji (1) pengaruh negatif ukuran perusahaan, profitabilitas, leverage, kualitas auditor terhadap audit delay, (2) pengaruh positif audit delay terhadap audit switching, dan (3) pengaruh positif audit delay dan audit switching terhadap kualitas audit. Sampel terdiri dari perusahaan-perusahaan perbankan yang terdaftar di Bursa Efek Indonesia periode 2011-2014 dengan menggunakan teknik purposive sampling sehingga diperoleh 30 sampel dengan 120 amatan. Hasil penelitian menunjukkan bahwa (1) ukuran perusahaan dan leverage tidak berpengaruh terhadap audit delay; sedangkan profitabilitas dan kualitas auditor memiliki pengaruh positif dan signifikan terhadap audit delay; (2) audit delay memiliki pengaruh positif dan signifikan terhadap audit switching; (3) audit delay memiliki pengaruh positif dan signifikan terhadap kualitas audit dan audit switching tidak berpengaruh terhadap kualitas audit.

Penelitian ini memiliki kontribusi antara lain (1) menambah literatur terkait anteseden dan konsekuensi audit delay pada perusahaan perbankan di Indonesia sebagai referensi pijakan penelitian akan datang; (2) sebagai bahan pertimbangan bagi auditor dalam menyelesaikan program audit untuk dapat menyelesaikan audit tepat waktu sesuai dengan regulasi yang telah ditetapkan oleh Otoritas Jasa Keuangan (OJK) sehingga kualitas audit menjadi meningkat; (3) membantu Otoritas Jasa Keuangan (OJK) dalam menentukan kebijakan regulasi terkait ketepatwaktuan penyampaian informasi pelaporan keuangan; serta (4) membantu pemangku kepentingan dalam menilai kondisi perusahaan sehingga mereka dapat memutuskan untuk melakukan investasi berdasarkan informasi yang tersedia dan memutuskan jenis auditor yang tepat digunakan dalam memitigasi adanya keterlambatan audit sehingga kualitas audit menjadi lebih baik.

\section{Keterbatasan dan Saran}

Keterbatasan dalam penelitian ini adalah (1) hasil penelitian tidak dapat digeneralisasikan untuk perusahaan nonperbankan yang terdaftar di Bursa Efek Indonesia sehingga diharapkan penelitian yang akan datang menggunakan sampel perusahaan yang selain sektor perbankan seperti sektor utama maupun sektor manufaktur; (2) penelitian ini tidak mempertimbangkan faktor-faktor lain yang relevan yang turut memengaruhi audit delay, audit switching dan kualitas audit sehingga 
diharapkan penelitian selanjutnya menambah variabel seperti opini audit, mekanisme corporate governance dan sistem pengendalian internal perusahaan; (3) ukuran sampel yang digunakan dalam penelitian ini relatif kecil karena hanya dibatasi pada sektor perbankan yang telah go public di Indonesia. Penelitian selanjutnya dapat menggunakan sektor perbankan sebagai sampel tetapi dengan menambah jumlah tahun yang lebih lama untuk melihat efek audit delay, audit switching dan kualitas audit.

\section{DAFTAR PUSTAKA}

(AICPA), American Institute of Certified Public Accountants. 1992. "Statement of position: Regarding mandatory rotation of audit firms of publicly held companies."

Abdulla, J. Y. A. 1996. "The timeliness of Bahrain annual reports." Advances in International Accounting 9 (1): 73-88.

Ahmad, Raja Adzrin Raja, dan Khairul Anuar Bin Kamarudin. 2003. "Audit delay and the timeliness of corporate reporting: Malaysian evidence." Faculty of Accountancy MARA University of Technology. 2003.

Ahmed, Kamran. 2003. "The Timeliness Of Corporate Reporting: A Comparative Study Of South Asia." Advances in International Accounting. https://doi.org/10.1016/S0897-3660(03)16002-3.

Al-Ajmi, Jasim. 2008. "Audit and reporting delays: Evidence from an emerging market." Advances in Accounting 24 (2): 217-26. https://doi.org/10.1016/j.adiac.2008.08.002.

Al-Ghanem, Wafa, dan Mohamed Hegazy. 2011. "An empirical analysis of audit delays and timeliness of corporate financial reporting in Kuwait." Eurasian $\begin{array}{llll}\text { Business } & \text { Review } & 1 & \text { (1): }\end{array}$ https://doi.org/http://www.ebesweb.org/Publications/Eurasian-BusinessReview/Archive.aspx.

Almosa, A.S, dan M. Alabbas. 2007. "Audit delay: Evidence from listed joint stock companies in Saudi Arabia." King Khalid University, Abha, Saudi Arabia, 2007.

Aryati, Titik. 2005. "Faktor-faktor yang mempengaruhi audit delay dan timeliness." Media Riset Akuntansi, Auditing dan Informasi 5 (3): 271-87.

Ashton, Robert H., Paul R. Graul, dan James D. Newton. 1989. “Audit delay and the timeliness of corporate reporting." Contemporary Accounting Research 5 (2): 657-73. https://doi.org/10.1111/j.1911-3846.1989.tb00732.x.

Ayemere, Ibadin Lawrence, dan Afensimi Elijah. 2015. "Corporate attributes and audit delay in emerging markets: Empirical from Nigeria." International Journal of Business, Accounting, \& Social Research 5 (3): 1-10. 
Bamber, E Michael, Linda Smith Bamber, dan Michael P Schoderbek. 1993. "Audit Structure and Other Determinants of Audit Report Lag: An Empirical Analysis." Auditing $12 \quad$ (1): $1-23$. https://doi.org/10.1017/CBO9781107415324.004.

Cameran, Mara, Annalisa Prencipe, Marco Trombetta, dan Management Control. 2016. "Does mandatory auditor rotation really improve audit quality? Does mandatory audit firm rotation really improve audit quality?" Bocconi University Milan Italy and Institute de Empresa Business School Spain, 2016. https://doi.org/10.1080/09638180.2014.921446.

Carey, Peter, dan Roger Simnett. 2006. "Audit partner tenure and audit quality." $\begin{array}{lllll}\text { Accounting } & \text { Review } & 81 & \text { (3): }\end{array}$ https://doi.org/10.2308/accr.2006.81.3.653.

Carslaw, Charles a. P. N., dan Steven E. Kaplan. 1991. "An Examination of Audit Delay: Further Evidence from New Zealand." Accounting and Business Research 22 (85): 21-32. https://doi.org/10.1080/00014788.1991.9729414.

Chadegani, Arezoo Aghaei, Zakiah Muhammaddun Mohamed, dan Azam Jari. 2011. "The Determinant Factors of Auditor Switch among Companies Listed on Tehran Stock Exchange." International Research Journal of Finance and Economics, 2011.

Che-Ahmad, Ayoib, dan Shamharir Abidin. 2008. "Audit delay of listed companies: A case of Malaysia." International business research 1 (4): 32-39. https://doi.org/10.5539/ibr.v1n4p32.

Chung, Hyeesoo Hyung. 2004. "Selective mandatory auditor rotation and audit quality: An empirical investigation of auditor designation policy in Korea."

Courtis, John K. 1976. "Relationships between timeliness in corporate reporting and corporate attributes." Accounting and Business Research 6 (25): 45-56. https://doi.org/10.1080/00014788.1976.9729085.

Davies, B., dan G. P. Whittred. 1980. "The Association Between Selected Corporate: Attributes and Timeliness in Corporate: Reporting: Further Analysis." Abacus 16 (1): 48-60. https://doi.org/10.1111/j.1467-6281.1980.tb00085.x.

DeAngelo, Linda Elizabeth. 1981. "Auditor size and audit quality." Journal of Accounting and Economics 3 (3): 183-99. https://doi.org/10.1016/01654101(81)90002-1.

Deloof, M., dan V. Weet. 2003. "External financing, information disclosure and the timeliness of annual shareholder meetings and financial filings in Belgium." Deloitte \& Touche Belgium, 2003.

Dopuch, Nicholas, Ronald R. King, dan Rachel Schwartz. 2001. "An experimental investigation of retention and rotation requirements." Journal of Accounting 
Research 39 (1): 93-117. https://doi.org/10.1111/1475-679X.00005.

Dyer, James C., dan Arthur J. McHugh. 1975. "The Timeliness of the Australian Annual Report." Journal of Accounting Research 13 (2): 204-20. https://doi.org/10.2307/2490361.

Enofe, Augustine O, Osarumwense O Ediae, dan Ejiemen C Okunega. 2013. "Audit Delay and Audit Quality: The Nigerian experience." Research Journal of Social Science \& Management 3 (4): 75-83.

Fagbemi, Temitope Olamide, dan Olayinka Marte Uadiale. 2011. "An Appraisal of the Determinants of Timeliness of Audit Report in Nigeria: Evidence from Selected Quoted Companies." In New Orleans International Academic Conference 2011, 355-72.

Fairchild, Richard J. 2007. "Does audit tenure lead to more fraud? A game theoretic approach."

Freeman, R. Edward. 1994. "The Politics of Stakeholder Theory: Some Future Directions." Business Ethics Quarterly 4 (4): 409-21. https://doi.org/10.2307/3857340.

Garsombke, H.P. 1981. "The timeliness of corporate financial disclosure, in J.K Courtis." Communication via anual report University of New England, 1981.

Giling, Donald M. 1977. "The timeliness in corporate reporting: Some further comment." Accounting and Business Research 8 (29): 34-36. https://doi.org/https://doi.org/10.1080/00014788.1977.9729106.

Givoly, Dan, dan Dan Palmon. 1982. "Timeliness of Annual Earnings Announcements: Some Empirical Evidence." The Accounting Review 57 (3): 486-508.

Gujarati, D. 2003. Ekonometrika Dasar. 6ed. Jakarta: Erlangga.

Hamilton, Jane, Caitlin Ruddock, Donald Stokes, dan Stephen Taylor. 2005. "Audit partner rotation, earnings quality and earnings conservatism."

Healey, T.J, dan Y.J Kim. 2003. "The benefits of mandatory auditor rotation." Regulation 26 (3): 10-11.

Hossain, Monirul Alam, dan Peter J. Taylor. 1998. “An examination of audit delay: Evidence from Pakistan."

Ibadin, Izilin Mavis, Famous Izedonmi, dan Peter Okoeguale Ibadin. 2012. "The association between selected corporate governance attributes, company attributes and timeliness off financial reporting in Nigeria." Research Journal of Finance and Accounting 3 (9): 137-44.

Ismail, Ku Nor Izah, dan Roy Chandler. 2004. "The timeliness of quarterly financial reports of companies in Malaysia." Asian Review of Accounting 12 (1): 1-18. 
https://doi.org/10.1108/eb060770.

Jaggi, Bikki, dan Judy Tsui. 1999. "Determinants of audit report lag: Further evidence from Hong Kong." Accounting and Business Research 30 (1): 17-28. https://doi.org/10.1080/00014788.1999.9728921.

Jensen, Michael C., dan William H. Meckling. 1976. "Theory of the firm: Managerial behavior, agency costs and ownership structure." Journal of Financial Economics 3 (4): 305-60. https://doi.org/10.1016/0304-405X(76)90026-X.

Kartika, Andi. 2011. "Faktor-faktor yang mempengaruhi audit delay pada perusahaan manufaktur yang terdaftar di BEI." Dinamika Keuangan dan Perbankan 3 (2): 152-71. https://doi.org/ISSN : 1979-4878.

Leventis, Stergios, Pauline Weetman, dan Constantinos Caramanis. 2005. "Determinants of audit Report Lag: Some Evidence From the Athens Stock Exchange." International Journal of Auditing 9 (1): 45-58. https://doi.org/10.1111/j.1099-1123.2005.00101.x.

Mgbame, Chijoke Oscar, Eragbhe Emmanuel, dan Nosakhare Peter Osazuwa. 2012. "Audit Partner Tenure and Audit Quality: An Empirical Analysis." European Journal of Business and Management 4 (7): 2222-2839.

Modugu et al. 2012. "Determinants of audit delay in Nigerian companies: empirical evidence." Research Journal of Finance and Accounting 3 (6): 1-10.

Nasser, Abu Thahir Abdul, Emelin Abdul Wahid, Sharifah Nazatul Faiza Syed Mustapha Nazri, dan Mohammad Hudaib. 2006. "Auditor-client relationship: The case of audit tenure and auditor switching in Malaysia." Managerial $\begin{array}{llll}\text { Auditing } & \text { Journal } & 21 & \text { (7): }\end{array}$ https://doi.org/10.1108/02686900610680512.

Newton, James D, dan Robert H Ashton. 1989. "The association between audit technology and audit delay." Auditing: A Journal of Practice and Theory.

Ng, Patrick P.H., dan Benjamin Y.K. Tai. 1994. "An empirical examination of the determinants of audit delay in hong kong." The British Accounting Review 26 (1): 43-59. https://doi.org/10.1006/bare.1994.1005.

Owusu-Ansah, Stephen. 2000. "Timeliness of corporate financial reporting in emerging capital markets: Empirical evidence from the Zimbabwe Stock Exchange." Accounting and Business Research 30 (3): 241-54. https://doi.org/10.1080/00014788.2000.9728939.

Prabowo, Pebi Putra Tri, dan Marsono. 2013. "Faktor-faktor yang mempengaruhi audit delay." DIPONEGORO JOURNAL OF ACCOUNTING 2 (1): 1-11.

Santoso, S. 2010. Statistik Multivariat Konsep dan Aplikasi dengan SPSS. Jakarta: PT Elex Media Komputindo. 
Schwartz, Kenneth B., dan Billy S. Soo. 1996. "The association between auditor changes and reporting lags." Contemporary Accounting Research 13 (1): 35370. https://doi.org/10.1111/j.1911-3846.1996.tb00505.x.

Siegel, Philip H., Mohsen Naser-Tavakolian, dan John J. O’Shaughnessy. 2008. "Factors influencing auditor switching in the European Union, Florida Atlantic University."

Stocken, M.E. 2000. “Auditor conservatism and opinion shopping: Influence of client switching expectations on audit opinion decision."

Vuko, Tina, dan Marko Cular. 2014. "Finding determinants of audit delay by pooled OLS regression analysis." Croatian Operational Research Review 5 (1): 8191. https://doi.org/10.17535/crorr.2014.0030.

Watkins, Ann L., William Hillison, dan Susan E. Morecroft. 2004. "Audit Quality: a Synthesis of Theory and Empirical Evidence." Journal of Accounting Literature 23 (1): 153-93.

Wirakusuma, Made Gede. 2004. "Faktor-Faktor yang mempengaruhi rentang waktu penyajian laporan keuangan ke publik." Seminar Nasional Akuntansi VII, 2004.

Yazawa, Kenichi. 2014. "Does audit partner rotation enhance audit quality? Evidence From Japan.” 


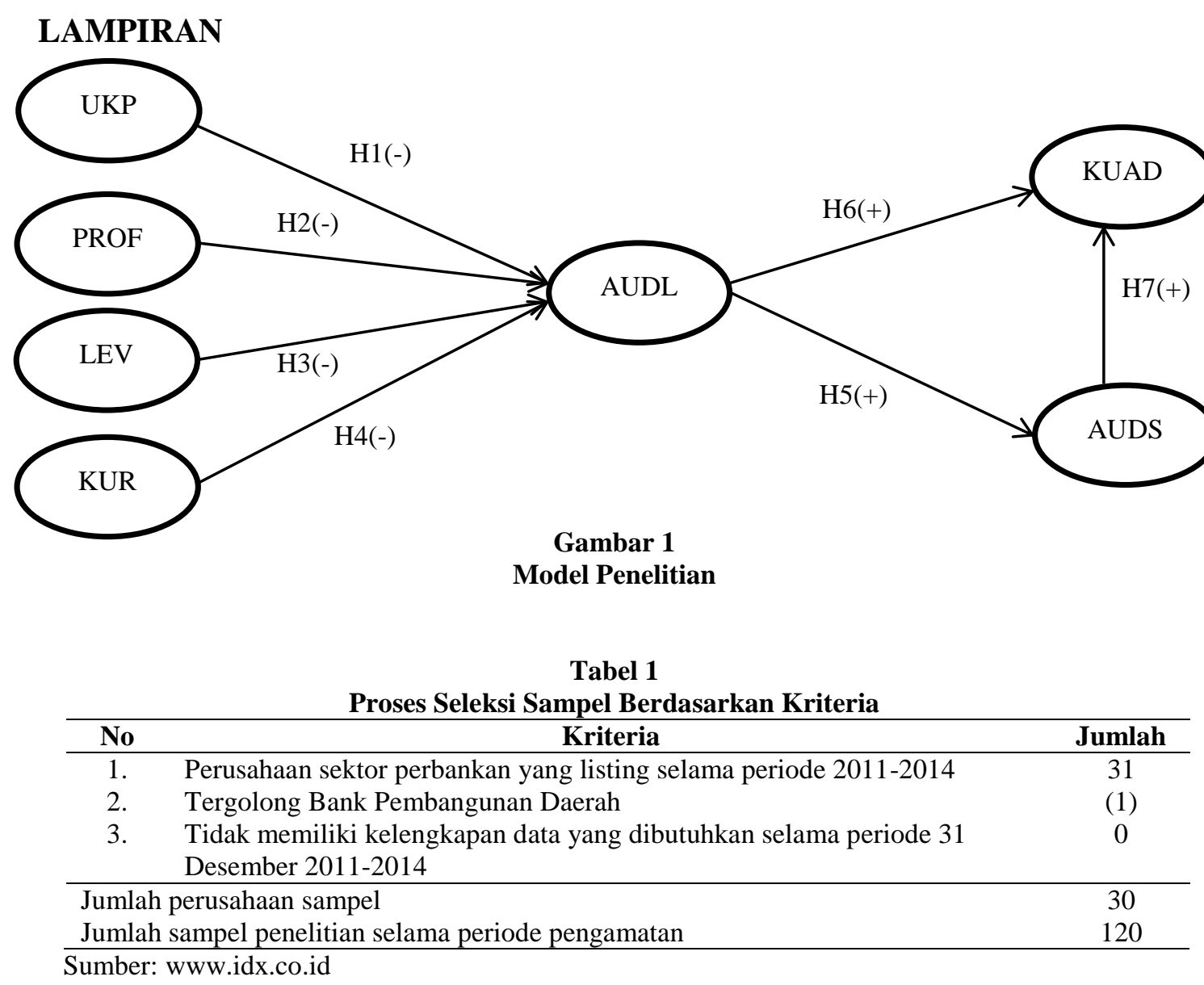

Tabel 2

Klasifikasi Data Audit Delay

\begin{tabular}{|c|c|c|c|c|c|c|c|c|}
\hline \multirow{3}{*}{ Keterangan } & \multicolumn{8}{|c|}{ Tahun } \\
\hline & \multicolumn{2}{|c|}{2011} & \multicolumn{2}{|c|}{2012} & \multicolumn{2}{|c|}{2013} & \multicolumn{2}{|c|}{2014} \\
\hline & Jumlah & $\%$ & Jumlah & $\%$ & Jumlah & $\%$ & Jumlah & $\%$ \\
\hline Audit Delay $<90$ hari & 29 & 96,67 & 28 & 93,33 & 29 & 96,67 & 30 & 100 \\
\hline Audit Delay $<90$ hari & 1 & 3,33 & 2 & 6,67 & 1 & 3,33 & 0 & 0 \\
\hline Jumlah & 30 & 100 & 30 & 100 & 30 & 100 & 30 & 100 \\
\hline
\end{tabular}

Sumber: Data diolah, 2015

Tabel 3

Statistik Deskriptif

\begin{tabular}{llllll}
\hline \multicolumn{1}{c}{ Variabel } & \multicolumn{1}{c}{ Mean } & \multicolumn{1}{c}{ Min } & \multicolumn{1}{c}{ Max } & \multicolumn{1}{c}{ StdDev } & Observasi \\
\hline Ukuran Perusahaan & $2,4702 \mathrm{E} 11$ & 1217521,00 & $5,20 \mathrm{E} 12$ & $9,50184 \mathrm{E} 11$ & 120 \\
LN Ukuran Perusahaan & 19,4033 & 14,01 & 29,28 & 3,53900 & 120 \\
ROA & 1,1792 & $-7,79$ & 3,41 & 1,43101 & 120 \\
Leverage & 763,2227 & $-743,92$ & 1562,03 & 309,17839 & 120 \\
Audit Delay & 64,5750 & 16,00 & 136,00 & 21,00527 & 120 \\
\hline Sumber
\end{tabular}

Sumber: Data diolah, 2015 
Tabel 4

Hasil Pengujian Asumsi Klasik

\begin{tabular}{|c|c|c|c|c|c|c|}
\hline \multirow{3}{*}{$\begin{array}{c}\text { Pengujian Asumsi } \\
\text { Klasik }\end{array}$} & \multirow{3}{*}{ Tipe Pengujian } & \multirow{2}{*}{\multicolumn{4}{|c|}{ Variabel }} & \multirow{3}{*}{ Keterangan } \\
\hline & & & & & & \\
\hline & & UKP & PROF & LEV & KUR & \\
\hline \multirow[t]{3}{*}{ Normalitas } & Kolmogorov- & 0,994 & 0,745 & 0,814 & 0,739 & \multirow{3}{*}{ Normal } \\
\hline & Smirnov & & & & & \\
\hline & Signifikansi & 0,277 & 0,635 & 0,522 & 0,645 & \\
\hline \multirow[t]{2}{*}{ Multikolinearitas } & Tollerance & 0,889 & 0,789 & 0,912 & 0,841 & \multirow{2}{*}{ Bebas Multikolinearitas } \\
\hline & $V I F$ & 1,125 & 1,267 & 1,097 & 1,189 & \\
\hline Heteroskedastisitas & Glejser (Sig.) & 0,876 & 0,845 & 0,862 & 0,151 & Bebas Heteroskedastisitas \\
\hline Autokorelasi & Durbin-Watson & 1,283 & & & & Bebas Autokorelasi \\
\hline
\end{tabular}

Sumber: Data diolah, 2015

Tabel 5

Hasil Pengujian Hipotesis

\begin{tabular}{llllllll}
\hline \multirow{2}{*}{ Variabel } & \multicolumn{3}{c}{ Model Persamaan I } & \multicolumn{2}{c}{ Model Persamaan II } & \multicolumn{2}{c}{ Model Persamaan III } \\
\cline { 2 - 7 } & Koefisien & t-value & $\boldsymbol{p}$-value & Koefisien & p-value & Koefisien & p-value \\
\hline UKP & 0,452 & 0,925 & 0,358 & & & & \\
ROA & $-3,783$ & $-2,949$ & 0,004 & & & & \\
LEV & 0,002 & 0,274 & 0,784 & & & & \\
KUR & $-18,610$ & $-4,776$ & 0,000 & & & & \\
AUDL & & & & 0,031 & 0,017 & 0,051 & 0,002 \\
AUDS & & & & & & $-0,592$ & 0,505 \\
\hline
\end{tabular}

\begin{tabular}{lll}
$R^{2}=0,307$ & Chi-Square $=12,358$ & Chi-Square $=8,880$ \\
Adjusted $R^{2}=0,282$ & Sig. $=0,136$ & Sig. $=0,353$ \\
Std Error of Est $=17,79330$ & -2 LL $($ Blok Number $=0)=112,442$ & -2 LL $($ Blok Number $=0)=86,232$ \\
$F=12,710$ & -2 LL $($ Blok Number $=1)=107,714$ & $-2 \operatorname{LL}($ Blok Number $=1)=80,516$ \\
Sig. $=0,000$ & Cox \& Snell Rsquare $=0,052$ & Cox \& Snell Rsquare $=0,086$ \\
Signifikansi 0,05 & Negelkerke $R$ Square $=0,086$ & Negelkerke $R$ Square $=0,173$ \\
\hline
\end{tabular}

Sumber: Data diolah, 2015 